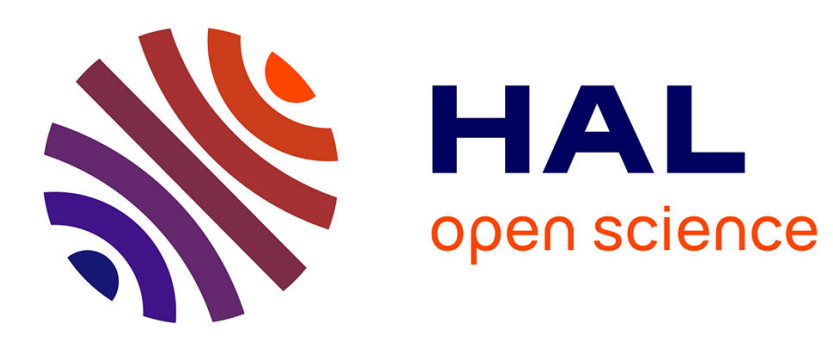

\title{
The not-so-odd couple: Odd pricing in a luxury context
}

\author{
Annalisa Fraccaro, Sandrine Macé, Béatrice Parguel
}

\section{To cite this version:}

Annalisa Fraccaro, Sandrine Macé, Béatrice Parguel. The not-so-odd couple: Odd pricing in a luxury context. Journal of Business Research, Elsevier, 2021, 136, pp.356-365. 10.1016/j.jbusres.2021.07.048 . halshs-03503449

\section{HAL Id: halshs-03503449 https://halshs.archives-ouvertes.fr/halshs-03503449}

Submitted on 27 Dec 2021

HAL is a multi-disciplinary open access archive for the deposit and dissemination of scientific research documents, whether they are published or not. The documents may come from teaching and research institutions in France or abroad, or from public or private research centers.
L'archive ouverte pluridisciplinaire HAL, est destinée au dépôt et à la diffusion de documents scientifiques de niveau recherche, publiés ou non, émanant des établissements d'enseignement et de recherche français ou étrangers, des laboratoires publics ou privés. 


\title{
The not-so-odd couple: Odd pricing in a luxury context
}

\section{Annalisa Fraccaro Sandrine Macé Béatrice Parguel}

\begin{abstract}
Two large samples of prices indicate that odd prices (i.e., prices just below a round number, for example $€ 1,495$ vs. $€ 1,500)$ are used in the pricing of luxury products. An analysis of price endings suggests that luxury brand managers rely less on the drop-off mechanism than on the meaning mechanism, both of which have been used to show that odd prices influence consumers in the Fast-Moving Consumer Goods (FMCG) industry. Building on the odd-ending price justification effect, a conjoint analysis, indicating that a large proportion of luxury consumers prefer odd prices, supports the likely role of a guilt-relief mechanism in the pricing of luxury products.
\end{abstract}

Keywords: Odd pricing. Luxury consumption. Justification effect. Conjoint analysis 


\section{Introduction}

Odd pricing, defined as "the practice of choosing a price's ending (i.e., its rightmost digits) so that the price falls just below a round number" (Schindler \& Wiman, 1989: 165), for example $€ 1.99$ vs. $€ 2$, has been widely investigated in the Fast-Moving Consumer Goods (FMCG) industry. In this industry, odd prices are used more frequently than other prices (Macé, 2012) because they convey favorable perceptions of value, and result in increased demand and sales (Freling et al., 2010). However, research has generally focused on products priced below $\$ 100$ or $€ 100$, with only a few exceptions e.g., in the laptop (i.e., Choi et al., 2014 ; Baumgartner \& Steiner, 2007) and housing (i.e., Allen \& Dare, 2004) industries. No research has ever been conducted on odd pricing in the luxury industry, for several reasons.

First, real-world data on the luxury market is extremely scarce as compared to FMCG markets. Second, pricing practices around luxury products have traditionally attracted scant attention, because of the general consensus that luxury consumers are not priceaverse, and that luxury brands should not display prices (Parguel et al., 2016). Third, and most importantly, odd prices are unexpected in the luxury industry, since prior studies highlight that they communicate images of both high-value-for-money and lowquality (Schindler, 1991; Schindler \& Kibarian, 2001). This is clearly at variance with the main principle of prestige pricing, i.e., "setting a rather high price to suggest high quality or high status" (Perreault \& McCarthy, 1999: 506). From this perspective, the use of odd prices for luxury products would appear to be both inappropriate and suboptimal.

However, in this paper, we contend that odd prices are indeed commonly used for luxury products. Whilst luxury pricing managers do not use cents, digits or 9-ending prices, they do indeed use prices ending in "90-something", which we consider to be 
odd prices, following Schindler and Kirby's (1997) intuition about the need to adjust the number of rightmost digits included in price-ending observations to the length of the price. More specifically, we investigate the circumstances in which odd prices are used in a luxury context, and whether luxury consumers might in fact prefer odd prices to other prices. The research presented here sets out to answer these questions by investigating both managerial practices and consumer preferences regarding priceendings.

We conduct three studies. Study 1 confirms that pricing managers set odd prices for luxury handbags, and that they do so based on specific beliefs about both the drop-off and the meaning mechanisms that have traditionally been used to account for the effects of odd pricing in the FMCG industry (e.g., Schindler et al., 2011; Stiving \& Winer, 1997). Study 2 extends this investigation by showing that managers operating in the luxury apparel industry rely more on the meaning mechanism than the drop-off mechanism. Finally, Study 3 uses a choice-based conjoint (CBC) analysis to show that luxury consumers prefer odd-priced over non-odd-priced products. As such, this study supports the odd-ending price justification effect (OPJE), according to which odd prices reduce the anticipated guilt usually associated with the purchase of hedonic products (Choi et al., 2014). The following sections of the paper explain the conceptual framework and hypotheses, present each study in turn, and finally provide a discussion of noteworthy findings.

\section{Conceptual framework}

In line with Schindler and Kirby (1997), we propose defining odd prices for the luxury industry as prices whose ending is up to 10 units below any given hundred, and even prices as prices ending in 00. If luxury brand managers used a simple "cost-plus" 
pricing approach (Dholakia, 2018), the distribution of price-endings would be random, resulting in all price-endings having an equal probability of occurrence. Still, if these managers do indeed make explicit choices about price-endings, we would expect to observe mostly even prices, given that they are supposed to convey an image of high quality and prestige, as they imply that customers are "above even thinking about pennies" (Schindler, 1991: 797). Furthermore, we would expect to observe almost no odd prices, since they are supposed to convey a low-price image (Naipaul \& Parsa, 2001; Stiving, 2000). In contradiction with this view, we propose considering odd pricing in the luxury industry as a "managerial dominant logic" (Prahalad \& Bettis, 1986), based on personal beliefs about the effects of odd pricing. More specifically, we assert that pricing managers in the luxury industry may indeed set odd prices as an indication of high value for money (Inman, McAlister \& Hoyer, 1990), in order to alleviate any anticipated guilt that may occur when considering purchasing luxury products (Choi et al., 2014). Below, we formulate Hypothesis 1 as follows:

H1: Luxury products display odd prices more often than chance would predict.

\section{Odd pricing as a guilt-reduction mechanism}

The purchase of unnecessary items is difficult to justify from a moral point of view (Okada, 2005). It therefore follows that indulging in the purchase of luxury items can produce negative self-attributions, resulting in feelings of guilt (Dahl et al., 2003), which may discourage the consumer from purchasing and reduce post-purchase satisfaction (Prelec \& Loewenstein, 1998). Managers in the luxury industry must, therefore, take proactive steps to provide consumers with an easily-accepted justification for self-indulgence, thereby mitigating such negative feelings. Good deals can act as such a guilt-reduction mechanism (Khan \& Dhar, 2010). Odd prices, because 
they are associated with good deals, also provide consumers with a justification for hedonic consumption. Choi et al. (2014) label this effect "OPJE" (Odd Pricing Justification Effect) in a study demonstrating that odd pricing encourages consumers to choose a personal computer which possesses hedonic (vs. utilitarian) attributes through a reduction in anticipated guilt. The OPJE could very well extend from hedonic to luxury consumption, which is frequently presented as being experiential, multisensorial, and a source of intrinsic pleasure (Wiedmann et al., 2009).

Nevertheless, Choi et al. (2014) do not discuss the rationale that leads pricing managers to consider odd pricing as an efficient way of signaling good deals and providing consumers with a justification for luxury consumption. In line with Schindler et al. (2011), we assume that pricing managers in the luxury industry set odd prices due to their beliefs about one or both mechanism(s) that are usually used to account for the effect of price-endings in the FMCG industry, i.e., the drop-off mechanism and the meaning mechanism. More specifically, we contend that they set odd prices when they want to signal good deals, and to alleviate the anticipated guilt associated with luxury consumption, but they do not set odd prices when they want to promote an “inaccessible" luxury positioning.

\section{The drop-off mechanism}

Pricing managers may believe that odd prices are underestimated by consumers due to the drop-off mechanism, i.e., the fact that "consumers drop off, ignore, presume, or in some way give insufficient consideration to a price's rightmost digits" (Schindler et al., 2011: 422). The drop-off mechanism may result from consumers rounding down prices (e.g., 49 is perceived as " 40 -something"), processing price information from left to right, or only remembering the leftmost digits because of limited memory capacity (Stiving \& Winer, 1997). Going further, Schindler and Kirby (1997) find that odd prices 
are used more for "high-potential underestimation" prices, i.e., where they cause the leftmost digit to decrease, as compared to when they cause only the second- or thirdfrom-leftmost digit to decrease. The same should apply for luxury items with higher prices, i.e., odd pricing should be more frequent when it causes the leftmost digit to decrease (as would occur in the case of $\$ 1,990$ vs. $\$ 2,000$ ) than when it causes only the second- or third-from-leftmost digit to decrease (e.g., \$1,890 vs. \$1,900).

However, we argue that the potential for underestimation is not just a matter of changing the leftmost digit; it can also be due to the crossing of a salient price threshold (Monroe, 1973). Allen and Dare (2004) show the high proportion of listed prices ending not only in 9,900 but also in 4,900, in the housing market. In line with Dehaene and Mehler's (1992) suggestion that " 0 " and " 5 " can both be considered as round numbers because of their high cognitive accessibility, we posit that "5", just like "0", can be considered as a salient threshold. It is probably because we use our 10 fingers for counting that "5" has a special status (Schindler \& Kirby, 1997). When we cross "5", we change hands, so we go from one half to the other half, which is highly salient from a cognitive perspective.

The notion that " 5 " is a salient number is quite unusual. However, " 5 " is a frequent price ending (Schindler \& Kirby, 1997). It appears as the most popular rightmost digit (71\%) on restaurant menus for meals priced from $\$ 7$ to $\$ 10.99$ (Kreul, 1982) and it is one of the most frequent rightmost digits for fine-dining restaurants (Naipaul \& Parsa, 2001). Using store-level scanner data for ten food and non-food product categories, Macé (2012) shows that "5" is the second most common rightmost digit in prices. Because of its frequency, the digit " 5 " structures consumers' mental representations (Dehaene \& Mehler, 1992) regarding prices: it acts as a midpoint. We contend that the drop-off mechanism may result from consumers rounding prices to the first "half" of the 
thousand (i.e., staying within the first 500) when the digit in the hundreds place is a " 4 ", but to the second "half" of the thousand when the digit in the hundreds place is a "5". We thus expect to find greater potential for underestimation when odd pricing causes the digit in the hundreds place to cross a " 5 " threshold (e.g., $\$ 1,490$ vs. $\$ 1,500$ ) or a "0" threshold (e.g., \$1,990 vs. \$2,000).

To sum up, if pricing managers believe in the drop-off mechanism, we should observe more odd prices when the digit in the hundreds place is a " 4 " or a "9". Therefore, we formulate Hypothesis 2 as follows:

H2: The probability of setting odd prices for luxury products

(a) is higher when the digit in the hundreds place is a "4";

(b) is higher when the digit in the hundreds place is a "9".

\section{The meaning mechanism}

The rightmost digits of prices convey meanings, i.e., they bring "information or thoughts about the price or about a non-price attribute of the product or retailer" (Schindler, 1991: 794). From repeated exposure to specific digits as the rightmost digits of prices (Schindler, 2006), consumers have learned that price-endings signify something meaningful about the products' value proposition (Naipaul \& Parsa, 2001). In particular, odd prices connote low, reduced or discount prices, and low-quality products (Schindler \& Kibarian, 2001). As such, they can put premium brands at risk (Macé, 2012), which could lead pricing managers in the luxury industry to strategically use or avoid them, depending on the circumstances.

First, luxury brand managers who believe in the meaning mechanism might assume that odd prices are more appropriate for more accessible, lower quality (i.e., made of less 
prestigious materials, such as canvas, rather than normal or exotic leather), cheaper and more conspicuous items, and thus avoid using odd prices for inaccessible pieces of craftmanship in order to protect their perceived luxury qualities. Relatively accessible luxury items mainly target "parvenus", who need to show off their status (Han et al., 2010). Because of this, accessible items are "louder" and more conspicuous (e.g., larger logos, repeat prints) than inaccessible items that usually target "patricians", who prefer more refined and discreet products. Inaccessible luxury goods are characterized by there being only very few units produced (sometimes only one), the use of premium materials, high prices, limited distribution, discreet communication and low brand prominence on the product itself.

Additionally, pricing managers in the luxury industry are inclined to set higher prices for new products. Early adopters are "expert consumers" of products: they tend to better appreciate the value provided by new products, and are in a hurry to consume them (Mahajan et al., 1990). As a result, these early adopters are usually non-price-sensitive, particularly so in luxury markets (Michman \& Mazze, 2006). Odd pricing may thus appear inappropriate in the introductory phase of the product life cycle. This is in sharp contrast with the FMCG industry, where odd prices signal an economic benefit, and aim to encourage consumers to try recently introduced products about which they lack information (Macé, 2012).

In line with the above discussion, we formulate Hypothesis 3 as follows:

H3: The probability of setting odd prices for luxury products:

(a) is higher for low-quality (vs. high-quality) items;

(b) is higher for conspicuous (vs. non-conspicuous) items;

(c) is higher for cheaper (vs. more expensive) items;

(d) is lower for new (vs. existent) items. 


\section{Consumer response to odd pricing}

Corroborating the meaning mechanism, odd pricing has been clearly shown to connote low, reduced or discount prices, and low-quality products (Schindler, 1991; Schindler \& Kibarian, 2001). We would thus expect consumers of luxury goods to avoid odd prices, as low-quality products do not meet consumers' needs when purchasing luxury goods, be they functional needs (i.e., a desire to consume excellence, sophistication, uniqueness), self-oriented needs (i.e., hedonism, materialism, self-expression), or social needs (i.e., conspicuousness, prestige) (Wiedmann et al., 2009).

However, this conjecture is open to challenge on two points. First, brands operating in the luxury industry are often well-established brands, dedicated to excellence and quality (Kapferer \& Bastien, 2012), with a high brand equity composed of numerous strong, favorable brand associations (Aaker, 1991; Keller, 1993) that protect them against any ad hoc information likely to convey negative connotations. The meaning mechanism might, therefore, have little or no impact on a well-established luxury brand's image. Second, and most importantly, odd prices encourage self-indulgence by reducing the guilt associated with luxury purchases. All things considered, consumers exposed to two comparable luxury products from well-established luxury brands should prefer an odd-priced (e.g., €1,590,€1,595) over a non-odd-priced item.

To test this conjecture, Hypothesis 4 is formulated as follows:

H4: Consumers prefer odd-priced (over non-odd-priced) luxury products.

We now test our hypotheses. Study 1 tests whether pricing managers: use odd prices (H1), believe in the drop-off mechanism (H2), or in the meaning mechanism (H3), or both, when setting odd prices for luxury handbags. Study 2 extends Study 1, using a 
different luxury category. Study 3 explores consumers' preference for odd-priced luxury products (H4).

\section{Study 1}

\section{Method}

To better understand managerial beliefs about odd pricing, directly questioning pricing managers from the luxury industry, as proposed by previous research (e.g., Blinder et al., 1998; Schindler et al., 2011), would appear unfeasible. Pricing managers, particularly in the luxury industry, are discreet about their pricing practices. Following Stiving (2000), we therefore chose to make inferences about managerial beliefs from the observation of Gucci and Louis Vuitton (hereinafter "LV") managers' price-ending practices in the luxury handbags industry.

Representing \$51 billion in annual retail sales in 2018, according to Bain \& Company, luxury handbags form the largest accessory segment in the market for personal luxury goods, a segment that experts consider to be "the engine that drives luxury brands today" (Thomas, 2007: 168). Since they do not require sizing, handbags are usually the most extensive product category that luxury brands offer, which means that numerous data points exist, and therefore statistical analysis is more reliable. As handbags cover several price ranges from the relatively accessible to the extremely expensive, they also provide external validity. As revealed in previous research (e.g., Han et al., 2010), Gucci and LV display extensive product lines of comparable size, making these brands of interest for further exploration. Furthermore, they are among the most valued luxury brands in the 2020 Interbrand ranking. 
Taking into account the fact that panel data for personal luxury goods do not exist, we collected prices online. Handbags sold online constitute a characteristic sample of what is sold in luxury brands' stores (Han et al., 2010), making our data representative of pricing practices both on- and off-line. As Gucci and LV are European brands, we collected prices in euros on their French websites for four "seasons" (from AutumnWinter 2013 to Spring-Summer 2015).

We identified the products' newness according to their availability in the previous season, before excluding Autumn-Winter 2013 data from the database, as we were unable to identify the products as being "just launched" or not. The final database comprised 1,490 observations (582 Gucci products and 908 LV products), including $14.9 \%$ of odd prices (i.e., price-ending in " 90 " or " 95 " only, as no price appears to end in "90-something else") over the three seasons.

Two dummies were introduced to operationalize product quality using the product material: canvas (37.1\% of the products), leather (51\% of the products) and exotic leather (i.e., python, ostrich, crocodile, representing $11.9 \%$ of the products). We coded product conspicuousness 1 if the $\log$ o was prominent, making the brand easily recognizable ( $62.5 \%$ of the products over the three seasons), and 0 otherwise. We coded the newness of the product 1 if the product had just been launched $(19.1 \%$ of the products over the three seasons), and 0 otherwise. Finally, we used two more dummies for the digit in the hundreds place $(8.6 \%$ of prices had a " 4 " in the hundreds place and $14.8 \%$ had a "9").

\section{Results}

The prices in the sample are all integers and 3-, 4- or 5-digit numbers (resp. 3.8\%, $95.6 \%$ and $0.6 \%$ ). Observing the rightmost digit, " 0 " is by far the most common rightmost digit (frequency of 92.1\%), followed by "5" (7.1\%) and then other digits 
(1\%). No "9" appears. Previous research has shown that, as the length of the price increases, it becomes necessary to look at more than just the final rightmost digit to identify price-endings (e.g., Schindler \& Kirby, 1997; Simmons \& Schindler, 2003). To go further, we therefore observe the two rightmost digits. Table 1 displays the distribution of two-digit price endings.

\section{Please insert Table 1 about here}

The distribution of the two rightmost digits displays three clear peaks: the first peak is for prices ending in " 00 " (frequency of $29.5 \%$ ), the second for prices ending in " 50 " (25.1\%) and the last for prices ending in "90" or "95" (14.9\%). None of the remaining price-endings exceed $2 \%$ frequency. Hence, in the luxury handbag category, where prices comprise at least three digits, the two rightmost digits determine the three most common price-endings: odd prices up to $€ 10$ below the round hundred (e.g., $€ 1,190$, $€ 1,195$ ), even prices ending in " 00 " (e.g., €1,200), and prices ending in "50" (e.g., $€ 1,150, € 1,250)$. Other prices end either in other round tens (e.g., $€ 1,920)$ or with a unit digit different from 0 (e.g., €244; labelled "Others" in Table 1).

Turning to the test of $\mathrm{H} 1$, odd prices appear with a global frequency of $14.9 \%$, which is significantly higher than chance alone would predict, i.e., $10 \%$ of the time $(Z=$ $6.261, p<.001)$. This overrepresentation is stronger when even prices ending in " 00 " are removed from the sample ( freq $=21.1 \%$ vs. $10.1 \%, Z=11.822, p<.001$ ), and when both even prices and prices ending in "50" are removed from the sample (freq = $32.8 \%$ vs. $10.2 \%, Z=19.379, p<.001$ ), which formally corroborates $\mathrm{H} 1$.

To test $\mathrm{H} 2$ and $\mathrm{H} 3$, we performed a binary logistic regression that explains the probability of a pricing manager setting an odd price by the brand, the digit in the hundreds place in the price, the product price itself, product quality, product 
conspicuousness and product newness. Due to potential multicollinearity, we standardized price, regressed it on brand, product quality, product conspicuousness and product newness, and then used the residual in the logistic regression. Table 2 displays the results of the logistic regression, which revealed a significant result.

\section{Please insert Table 2 about here}

The analyses show that odd prices are significantly more frequent when the digit in the hundreds place is a " 4 " $(\beta=0.99, p<.001)$ or a "9" $(\beta=0.65, p<.01)$, corroborating $\mathrm{H} 2 \mathrm{a}$ and $\mathrm{H} 2 \mathrm{~b}$. Furthermore, the handbag material has a significant influence on the probability of setting an odd price: odd prices are more frequent for canvas products $(\beta=0.97, p<.001)$ and less frequent for exotic leather products $(\beta=-3.05, p<.001)$ than for leather products, corroborating H3a. Odd pricing is also significantly more frequent for conspicuous (vs. non-conspicuous) products $(\beta=$ $0.70, p<.01$ ), corroborating H3b. Controlling for the other variables, odd prices become significantly rarer when the price increases $(\beta=-0.55, p<.05)$, supporting H3c. However, odd prices are not more (or less) frequent for new (vs. old) products, providing no support for $\mathrm{H} 3 \mathrm{~d}$.

\section{Discussion}

Behavioral decision theory seeks to account for how individuals make decisions (Slovic et al., 1977), i.e., "the mental (or cognitive) process of selecting a logical choice from several competing alternatives" (Swami, 2013: 204). In a marketing setting, it reveals the marketers' overall mental market model, which includes beliefs about market actors' responses and the context (Boulding et al., 1994). In line with behavioral decision theory, Study 1 provides support for the general hypothesis that, when setting odd

prices, luxury managers possess, and act upon, beliefs about both the drop-off 
mechanism (they are more likely to set odd prices when the digit in the hundreds place is a " 4 " or a "9") and the meaning mechanism (they reserve odd pricing for specific circumstances to minimize any potential negative image effect, i.e., for more "accessible" luxury products, supposedly when they want to signal relatively good deals). As previously suggested by research conducted on FMCG (e.g., Schindler, 1991; Stiving \& Winer, 1997), they seem to believe that the two mechanisms are not mutually exclusive, consciously or otherwise (Nightingale, 2007).

\section{Study 2}

Study 1 provides empirical evidence that both the drop-off and meaning mechanisms account for how pricing managers in the luxury handbag category set odd prices. Study 2 aims to replicate this finding in the luxury apparel category, which represented $€ 60$ billion in annual global retail sales in 2018 , according to Bain \& Company.

\section{Method}

Using the software ScrapeStorm, we scraped data from the French e-store of Net-aporter (https://www.net-a-porter.com/fr/en/), a website positioned as the world's premier online luxury fashion retailer, who reportedly aligns its prices with those recommended by brands (Business of Fashion, 2017). We collected data in December 2019. We only considered the five brands with the biggest product range available on Net-a-porter at the time of data collection, i.e., Balenciaga, Gucci, Miu Miu, Prada and YSL. These brands are commonly considered as luxury brands. Our database included the brand name, the product description (on average, 88 words per observation) and the price in euros for 1,078 observations (out of the 7,848 observations corresponding to the 
398 brands of the luxury apparel category). Table 3 provides the distribution of their two-digit price endings.

Please insert Table 3 about here

134 product descriptions were not provided. The final database comprised 944 observations, including $34.6 \%$ of odd prices (i.e., price-ending in "90", “91", “92” or "95" only, as no price appears to end in "90-something else"). Further descriptive statistics are available in the Web Appendix.

These data did not allow us to measure product newness, as we were unable to collect prices repeatedly over time; nor did we assess product conspicuousness, which implies that results for $\mathrm{H} 3 \mathrm{~b}$ and $\mathrm{H} 3 \mathrm{~d}$ cannot be replicated. Nonetheless, our data allowed us to retest our hypotheses regarding the digit in the hundreds place $(\mathrm{H} 2)$, product quality (H3a) and expensiveness (H3c). We used the same dummy variables for the digit in the hundreds place as in Study 1 (9.1\% of prices had a " 4 " in the hundreds place and $18.3 \%$ had a "9"). Product quality was operationalized using the product materials, as listed in the product description. Real leather (including exotic leather), silk, linen, wool and feathers were considered as premium materials. We then created a dummy variable for product quality depending on the presence of premium materials in the description of the product.

\section{Results}

To retest $\mathrm{H} 2$ and H3, we performed a binary logistic regression, as in Study 1. Table 4 displays its results.

Please insert Table 4 about here

The analyses show that odd prices are not more frequent when the digit in the hundreds place is a "4", and they are significantly less frequent when it is a "9" $(\beta=-0.78, p<$ 
$.01)$. This runs counter to $\mathrm{H} 2$ and expectations based on the drop-off mechanism. As regards price setting based on the meaning mechanism, odd prices are less frequent when products include premium materials $(\beta=-0.35, p<.01)$ and for prices that are higher $(\beta=-0.72, p<.001)$, replicating the results that corroborate $\mathrm{H} 3 \mathrm{a}$ and $\mathrm{H} 3 \mathrm{c}$.

\section{Discussion}

Study 2 supports our general proposition to consider odd pricing in the luxury industry as a dominant management logic. It challenges this proposition, however, regarding the specific beliefs upon which such a dominant logic is based. When setting odd prices, managers in the luxury apparel industry possess, and act on, beliefs about the meaning mechanisms, but not on beliefs about the drop-off mechanism: odd prices are not more frequent when the digit in the hundreds place is a " 4 ", and they are less frequent when it is a "9". Pricing managers in the luxury apparel industry may want to avoid overly obvious odd pricing, such as $€ 1,995$, which may give the impression that the brand is not being fully honest or straightforward (Schindler et al., 2011). They may thus be less willing to set odd prices when the potential for underestimation is too high (e.g., $€ 1,990$ vs. $€ 2,000$ ), which runs counter to previous results for the FMCG industry (Schindler \& Kirby, 1997). Favoring $€ 1,950$ or $€ 1,980$ over $€ 1,990$ may appear as a more discreet way of making use of the drop-off mechanism. Appearing in a more subtle way than in a FMCG context, the drop-off mechanism is less powerful than the meaning mechanism in shaping the pricing practices of luxury managers compared with their FMCG counterparts. 


\section{Study 3}

Study 1 and Study 2 support the proposition that pricing managers in the luxury industry believe it is beneficial to use odd pricing in specific circumstances where they want to signal relatively high value for money, and to alleviate the anticipated guilt associated with luxury consumption. In Study 3, we investigate consumers' preferences for odd-priced (over non-odd-priced) luxury products (H4).

\section{Method}

Following previous research on consumer preferences for odd pricing in a non-luxury context (e.g., Baumgartner \& Steiner, 2007; Gendall et al., 1998), we conducted a CBC analysis to test H4. Female alumnae of a major Paris business school were invited by email to participate in a CBC survey, of whom 340 completed it. As women are the buyers in four out of every five luxury purchases (Okonkwo, 2007), we only surveyed females. Although this potentially reduces external validity, it avoids any confounding gender effect, and is in line with previous research in the luxury literature (e.g., Janssen et al., 2014; Lee \& Watkins, 2016).

Participants were first asked questions about their luxury consumption, and they provided their sociodemographic details afterwards. To reach our luxury target group, we only considered participants with a monthly household income of more than $€ 3,000$ who declared they had made luxury purchases in the previous two years. This provided a sample of 169 female respondents, with an average age of 39, an average of 2.3 purchases of luxury products over the previous two years, and the following monthly household income distribution: $23 \%$ between $€ 3,000$ and $€ 4,999,44 \%$ between $€ 5,000$ and $€ 9,999,20 \%$ between $€ 10,000$ and $€ 14,999$, and $13 \%$ over $€ 15,000$. 
Participants were then invited to carry out a CBC task in the luxury handbag category, which involved three attributes: price-ending (four levels), brand (three well-established luxury brands: Gucci, Prada and YSL) and product size (three levels: small, medium and large). The price levels were based on the average prices of the three brands' handbags, so that they would be perceived as realistic. We set the odd price at $€ 1,595$, the even price at $€ 1,600$, and two control prices: $€ 1,560$ and $€ 1,640$. These control prices were set equidistant from the even price, in line with Baumgartner and Steiner (2007). There were 15 choice sets. Every choice set contained three different models, as illustrated by Figure 1.

Please insert Figure 1 about here

Choice sets were generated randomly with the balanced overlap option of Sawtooth Software. Each respondent saw 15 different screens with randomly-generated combinations of prices and branded products. We adopted a dual-response approach (Brazell et al., 2006; Orme \& Chrzan, 2017: 65, 124), in which respondents declared their preference among a set of available alternatives in a forced-choice task, before indicating whether or not they would purchase the product. The choice was modelled as a 2-stage process, such that respondents first decided among the three alternatives ("Between the following products, which one would you choose?") and then between the preferred alternative and the none ("Would you buy the handbag that you most preferred? Yes/No") (Wlömert \& Eggers, 2016; Diener et al., 2006). As in previous research (e.g., Brazell et al., 2006), the share of no-choice decisions was high (56.95\%), justifying the dual-response approach.

We used Sawtooth Software to estimate the part-worth utilities for individuals with a Hierarchical Bayesian model. The three attributes, i.e., price level, brand and product size, were treated as categorical dummies. We followed the default option for the 
distribution probabilities in the Hierarchical Bayesian model (Sawtooth Software, 2017), and a multivariate normal distribution was applied to the first-stage priors. The second-stage priors were inverse Wishart distributed. The estimation procedure comprises 20,000 iterations: 10,000 iterations for burning in and 10,000 iterations for the final estimations.

\section{Results}

The CBC analysis reveals that price-endings influence only $6.7 \%$ of choices (vs. $65.5 \%$ for the brand and $27.8 \%$ for the product size). Figure 2 displays the mean utilities and their uncertainty measured by the $95 \%$ credible interval (CI) that identifies the range in which there is a $95 \%$ probability that the true parameter value falls (Rossi et al., 2005).

Please insert Figure 2 about here

The values of the posterior means of the MCMC draws as parameter estimates for the price attribute level, and their CI are reported in Table 5. The estimated utilities for each attribute level (i.e., price, brand and size), the standard deviations as well as the CI are reported in the Web Appendix. To conclude whether we observed a significant impact of the odd ending on the preference, we reviewed the CI and considered the degree of confidence (DC) that the odd-priced product is preferred over the product priced at $€ 1,560$ (resp. $€ 1,600$ and $€ 1,640$ ) by counting the percentage of MCMC draws for which the part-worth utility estimate for the odd price is greater than the part-worth utility estimate for the price of $€ 1,560$ (resp. $€ 1,600$ and $€ 1,640$ ) (Orme \& Chrzan, 2017: 182-185).

The findings indicate significant differences across the utilities: the CI display no overlap, and the DC are greater than $99.75 \%$. The highest utility appears for the odd price of $€ 1,595$ (utility $=2.28, C I=[1.77 ; 2.81]$ ), which is notably preferred to 
$€ 1,560$ (utility $=0.95, \quad C I=[0.39 ; 1.52], \quad \mathrm{DC}=0.9975), € 1,600 \quad$ (utility $=0.06$, $C I=[-0.65 ; 0.77], \mathrm{DC}>0.9999)$ and $€ 1,640$ (utility $=-3.30, C I=[-3.92 ;-2.68]$, DC $>0.9999)$. Naturally, as a lower price, the odd price of $€ 1,595$ is preferred to the price of $€ 1,640$, but also to the even price of $€ 1,600$. Considering that, in luxury product categories, consumers do not usually react to price differences below 30\% (Kapferer \& Bastien, 2012), this significant response to a negligible difference of $€ 5$ (i.e., $0.3 \%$ ) is noticeable. No significant difference appears between the price of $€ 1,560$ and the price of $€ 1,600$. Altogether, these results corroborate H4, which postulates consumers' preference for odd-priced (over non-odd-priced) luxury products.

To refine the findings, we performed a hierarchical cluster analysis using a ward method and the squared Euclidean distance on all the individual utilities, in their normalized form. Table 5 displays the average utilities for the four selected clusters and their CI. It also reports the median, as opposed to the mean, purchase of luxury goods over the previous two years to control for extreme values sensitivity. A median test indicates significant overall differences of the median purchases of luxury goods across the clusters $(\mathrm{t}=10.3, \mathrm{p}<0.05)$.

\section{Please insert Table 5 about here}

The results indicate that price endings have no impact for subjects from Cluster 1 (25.5\% of the sample). For these subjects that display the fewest purchases of luxury goods, we observe the usual relationship, in which preferences decrease with price. For the three other clusters (2, 3 and 4$)$, the review of the $95 \%$ CI showing no overlap as well as the highest $\mathrm{DC}(\mathrm{DC}>0.99)$, provides strong confidence that the odd price, $€ 1,595$, is preferred to the lowest price of $€ 1,560$. Subjects from Cluster 2 and Cluster 3 (43.8\%) prefer the odd price to any other price, while subjects from Cluster $4(15 \%)$ that display the biggest purchases of luxury goods prefer even prices to any other prices. 
Finally, from the graph of utilities displayed in Figure 3, we observe an inverted Ushaped relation between preferences and prices for 3 clusters, with a peak at the odd price for medium luxury consumers (Cluster 2 and Cluster 3), and a peak at the even price for the biggest luxury consumers (Cluster 4). We observe that, for Clusters 2 and 3 , the utility curve for price endings, with a peak at 1,595 over 1,600 euros, hints at a step demand function, as suggested by previous literature (Gedenk \& Sattler, 1999).

Please insert Figure 3 about here

\section{Discussion}

Study 3 highlights a preference for odd-priced (over non-odd-priced) luxury products for a large proportion of consumers. For these consumers, the preference for the odd price, $€ 1,595$, over the even price, $€ 1,600$, notwithstanding the very small difference in price, is consistent with both the drop-off and the meaning mechanisms. Their preference for the odd price, $€ 1,595$, over the lowest price, $€ 1,560$, supports the meaning mechanism, as these two prices are in the same hundred, and not subject to the drop-off mechanism. Interestingly, the four clusters do not display any drop in utilities for the odd price, meaning that the negative connotations in terms of perceived quality that are likely to result from odd pricing (Schindler \& Kibarian, 2001) do not seem to affect luxury consumers' response. Also, negative connotations may appear negligible in the context of top luxury brands, which benefit from a large network of strong, positive associations with excellence and quality (Kapferer \& Bastien, 2012). It therefore follows that, consumers will rely less on price-related information to make judgments (Miyazaki et al., 2005), making brands less sensitive to potentially negative connotations related to price (Dall'Olmo et al., 2013; Parguel et al., 2016).

Altogether, these findings suggest that price should not be considered entirely as an objective attribute, but partially as a subjective product attribute, too (Monroe, 1973) 
from which to infer information (Kirmani \& Rao, 2000). From this perspective, in the luxury industry just as much as in the FMCG industry, odd pricing might constitute a signal of a good deal. Furthermore, price can also be considered from an affective perspective, with consumers forming attitudes based on the feelings and emotions associated with spending (Raghubir, 2006). In this second, non-cognitive perspective, odd pricing would act as a guilt-reduction mechanism, as proposed by Choi et al. (2014). As such, the greatest consumers of luxury goods, who may experience less guilt when purchasing expensive goods, are not sensitive to odd prices, and still prefer even prices, which are known for signaling high quality. On the whole, Study 3 supports a dual explanation for luxury consumers' preference for odd pricing, i.e., by an informational route (i.e., the drop-off and the meaning mechanisms) and an affective one (i.e., the guilt reduction mechanism). As such, Study 3 extends Choi et al.'s (2014) framework from utilitarian products (i.e., personal computers) to luxury products.

\section{General discussion}

Taken together, despite certain limitations that will be further discussed further, the three studies presented in this article provide noteworthy theoretical insights and interesting managerial implications for luxury brand managers involved in price-setting.

\section{Theoretical contributions}

This research makes an overall contribution to the literature on price-endings by showing that odd prices ending in " 90 " or "95" play a relevant role in a luxury context. Adopting the definition of odd prices as prices that fall "just below a round number" (Schindler \& Wiman, 1989: 165), we extend their domain of relevance from "9" or "99" price-endings to " 90 " or " 95 " price-endings as the price length increases. Other price 
endings in " 50 " or " 80 " call for further research in order to identify the circumstances in which such "compromise prices" are used.

We further contribute to the odd pricing literature by showing that the way managers in the luxury industry set odd prices is more consistent with the application of the meaning mechanism than of the drop-off mechanism. Specifically, as regards the drop-off mechanism, Study 1 shows that managers are more likely to set odd prices when the digit in the hundreds place has moderate potential for underestimation, but Study 2 did not replicate this result. Managerial practices are inconsistent regarding the fourth and the ninth hundred, as previously observed by Allen and Dare (2004). These practices differ from one product category and one brand to another. Turning to the meaning mechanism, we show that managers are more likely to set odd prices for conspicuous items, while they are less likely to set odd prices for more expensive yet more discreet, top-quality items. This dominant logic appears robust over time, across brands and product categories. Personal knowledge of, or expertise in, the FMCG industry (Prahalad \& Bettis, 1986) may explain why these managers have internalized its theoretical principles about odd pricing into their own managerial beliefs. Typical marketing syllabi tend to use the world of big FMCG businesses as their frame of reference (Martin \& Chapman, 2006); in addition, courses specifically devoted to pricing are very rare in undergraduate programs (McCaskey \& Brady, 2007). Nonetheless, while managers from the luxury industry anchor their beliefs about priceendings on what they learned about the FMCG industry to simplify decision-making (Simon, 1956), they also seem to adjust these beliefs to their specific luxury context. Their reluctance to use odd pricing as obviously as is the case in the FMCG industry (e.g., when the digit in the hundreds place is a "9") could be usefully explored in future research. 
This research is among the earliest studies to apply the concept of managerial beliefs (Prahalad \& Bettis, 1986) to marketers' decision-making. Recent strategic management research investigating managers' mental models has traditionally measured them using two methodological approaches (Vecchiato, 2017). The first uses extensive field studies, involving semi-structured interviews, to retrospectively explain organizational decision-making (with the risk of bias due to managers' post-rationalization, as managerial beliefs can operate at an unconscious level). The second uses managers' letters or speeches as proxies for their managerial beliefs (with a risk of bias due to availability of relevant public documents). Our own methodological approach, using a survey of real-life pricing decisions, is less constrained and has a lower risk of bias, as marketers make many easily-accessible decisions regarding product attributes. We thus claim that direct observation of the outputs of managers' decisions is a relevant alternative methodological approach when studying marketers' managerial beliefs.

Finally, Study 3 confirms that odd-priced products are preferred over non-odd-priced products by a large proportion of luxury consumers, meaning that odd prices can increase the likelihood of a luxury purchase, especially among medium luxury consumers, but not among the biggest luxury consumers. This finding, although it runs counter to previous literature, which associates odd pricing with both low-price and low-quality connotations, is consistent with Freling et al.'s (2010) suggestion that odd pricing could be even more effective for high-priced products. The findings from Study 1 and Study 2 also show that luxury pricing managers adopt odd pricing in specific circumstances when they want to signal high value for money, i.e., for conspicuous items, but not for more expensive, top-quality items. As a signal for good deals, odd pricing would then reduce guilt feelings in consumers considering spending on luxury, which is also consistent with the OPJE proposed by Choi et al. (2014). This 
corroborates $\mathrm{H} 4$, which specifically draws on the OPJE, and indirectly highlights how relevant this mechanism could be for luxury consumption.

\section{Managerial implications}

The finding that medium luxury consumers prefer odd pricing suggests that luxury managers should naturally consider using odd pricing to reduce anticipated guilt, and thus maximize their sales potential, thereby enabling them to benefit from higher unit margins. In particular, luxury managers could favor odd prices in spring to help deseasonalize sales by alleviating the anticipated guilt and encouraging self-indulgence (Clarke \& Mortimer, 2013). They could also set any other type of price-endings in autumn, just before Christmas, as gifting to others is intrinsically altruistic, and is not presumed to trigger feelings of guilt (Dubois \& Laurent, 1996).

In terms of product portfolio, luxury managers should opt for odd pricing for conspicuous products. Being motivated by the desire to signal wealth, status and social power (Veblen, 1989), conspicuous consumption triggers guilt (Ki et al., 2017) and, therefore, calls for a guilt-reduction mechanism. Odd pricing could thus be particularly relevant when consumption is driven by status display, rather than more personal reasons, i.e., when products are readily noticeable, such as when they display prominent logos or designs and are highly identifiable by others (e.g., monogrammed handbags). However, pricing managers should avoid odd pricing for more classic, iconic products, whose timelessness means they are also perceived as an investment (Kapferer \& Bastien, 2012), as this perception can in itself eradicate consumers' sense of guilt. Style consumption, i.e., consumption that is oriented towards the self and is aimed at selfextension, has been shown to reduce guilt in a luxury context (Ki et al., 2017). Extending this rationale, it would appear reasonable to assume that purchasing a formal item of clothing that can be worn on a daily basis in a business context involves less 
guilt than purchasing a handbag for purely leisure use. Therefore, we recommend applying fewer odd prices for formal, businesslike handbags and apparel, and more odd prices for handbags and apparel that are purchased for evening events or casual occasions.

Continuing with a product portfolio perspective, luxury managers should opt for odd pricing to encourage spontaneous, unplanned consumption, which has been shown to elicit guilt (Rook, 1987; Yi \& Baumgartner, 2011). Examples include cross-sold products and small leather goods such as wallets, key and card holders, or phone cases. Odd prices could also help to develop the see now/buy now concept invented by Burberry, in which products are made available online immediately after a live fashion show, with the significant objective of responding immediately to consumer impulses stimulated during the event. Finally, odd pricing could be used for fashionized product lines that are developed to follow emerging trends, and positioned closer to fast-fashion industry codes. Being limited editions, fashionized products are often bought on impulse, and there is a need to mitigate the anticipated guilt that can result from spending a large sum of money on an item that will go out of fashion very quickly.

\section{Limitations and future research}

First, our findings show that odd pricing is a common practice for products in the accessible and intermediate levels of luxury, and that, in the luxury handbag product category, consumers prefer odd pricing for top luxury brands. It is reasonable to believe that odd prices can be extended to other luxury product categories at the same levels of luxury. Future research could investigate prices of tens or hundreds of thousands of euros or dollars, or other currencies of much lower value, such as the Chinese yuan, and address the case of unfamiliar luxury brands, whose image could be negatively affected by odd pricing. It could also test whether odd pricing could be even more appreciated 
by less affluent consumers, hence contributing to attract "the mass of middle-class consumers" (Truong et al., 2009: 375) from the perspective of masstige strategies (Kastanakis \& Balabanis, 2012).

Second, our research shows that, in the real-life market, price-endings are consistent with drop-off and meaning mechanisms, leading us to conclude that luxury brand managers believe that odd pricing acts as a guilt-reduction mechanism. We leave it to further research to directly test the influence of odd pricing on the guilt that may be triggered by luxury purchases, and the potential mediating effect of perceived expensiveness in this influence.

Finally, while $\mathrm{CBC}$ utilities are often considered the best proxy for purchase intentions, our respondents were required to make 15 successive choices from similar items with randomized attributes. This task was repetitive, and we cannot rule out the possibility that some respondents may have ignored certain attributes after a few choice sets. Furthermore, the choices they had to make were virtual. Ideally, future research could analyze actual sales data, if luxury companies could be persuaded to share such data for the purposes of marketing research.

\section{References}

Aaker, D.A. (1991). Managing brand equity. New York, The Free Press.

Allen, M.T., \& Dare, W. H. (2004). The effects of charm listing prices on house transaction prices. Real Estate Economics, 32(4), 695-713.

Baumgartner, B., \& Steiner, W.J. (2007). Are consumers heterogeneous in their preferences for odd and even prices? Findings from a choice-based conjoint study. International Journal of Research in Marketing, 24(4), 312-323.

Blinder, A.S., Canetti, E.R. D., Lebow, D.E., \& Rudd, J.B. (1998). Asking about prices: A new approach to understanding price stickiness. New York, NY: Russell Sage Foundation. 
Boulding, W., Moore, M.C., Staelin, R., Corfman, K.P., Dickson, P.R., Fitzsimons, G., Gupta, S., Lehmann, D.R., Mitchell, D.J., Urbany, J.E., \& Weitz, B.A. (1994). Understanding managers' strategic decision-making process. Marketing Letters, 5(4), 413-426.

Brazell, J.D., Diener, C.G., Karniouchina, E., Moore, W.L., Séverin, V., \& Uldry, P.F. (2006). The no-choice option and dual response choice designs. Marketing Letters, 17(4), 255-268.

Choi, J., Li, Y.J., Rangan, P., Chatterjee, P., \& Singh, S.N. (2014). The odd-ending price justification effect: the influence of price-endings on hedonic and utilitarian consumption. Journal of the Academy of Marketing Science, 42(5), 545-557.

Clarke, P., \& Mortimer, G. (2013). Self-gifting guilt: an examination of self-gifting motivations and post-purchase regret. Journal of Consumer Marketing, 30(6), 472-483.

Dahl, D.W., Honea, H., \& Manchanda, R.V. (2003). The nature of self-reported guilt in consumption contexts. Marketing Letters, 14(3), 159-171.

Dall'Olmo Riley, F., Pina, J.M., \& Bravo, R. (2013). Downscale extensions: Consumer evaluation and feedback effects. Journal of Business Research, 66(2), 196-206.

Dehaene, S., \& Mehler, J. (1992). Cross-linguistic regularities in the frequency of number words. Cognition, 43(1), 1-29.

Diener, C., Orme, B., \& Yardley, D. (2006). Dual response "none" approaches: Theory and practice. Proceedings of the Sawtooth Software Conference, 157-168.

Dholakia, U.M. (2018). When cost-plus pricing is a good idea. Harvard Business Review.

Dubois, B., \& Laurent, G. (1996). The functions of luxury: A situational approach to excursionism. Advances in Consumer Research, 23(1), 470-477.

Freling, T., Vincent, L., Schindler, R., Hardesty, D., \& Rowe, J. (2010). A metaanalytic review of just-below pricing effects. Advances in Consumer Research Volume 37, eds. M.C. Campbell, J. Inman, and R. Pieters, Duluth, MN: Association for Consumer Research, 618-620.

Gendall, P., Fox, M.F., \& Wilton, P. (1998). Estimating the effect of odd pricing. Journal of Product \& Brand Management, 7(5), 421-432.

Hair, J., Black, W.C., Babin, B.J., \& Anderson, R.E. (2010) Multivariate data analysis (7th ed.). Upper Saddle River, New Jersey: Pearson Educational International.

Han, Y.J., Nunes, J.C., \& Drèze, X. (2010). Signaling status with luxury goods: The role of brand prominence. Journal of Marketing, 74(4), 15-30.

Inman, J.J., McAlister, L., \& Hoyer, W.D. (1990). Promotion signal: proxy for a price cut? Journal of Consumer Research, 17(1), 74-81. 
Janssen, C., Vanhamme, J., Lindgreen, A., \& Lefebvre, C. (2014). The catch-22 of responsible luxury: Effects of luxury product characteristics on consumers' perception of fit with corporate social responsibility. Journal of Business Ethics, 119(1), 45-57.

Kapferer, J.N. (2012). Abundant rarity: The key to luxury growth. Business Horizons, 55(5), 453-462.

Kapferer, J.N., \& Bastien, V. (2012). The luxury strategy: break the rules of marketing to build luxury brands. Kogan page publishers.

Kastanakis, M.N., \& Balabanis, G. (2012). Between the mass and the class: Antecedents of the «bandwagon » luxury consumption behavior. Journal of Business Research, 65(10), 1399-1407.

Keller K.L. (1993). Strategic brand management: Building, measuring, and managing brand equity. Upper Saddle River NJ: Prentice Hall.

Khan, U., \& Dhar, R. (2010). Price-framing effects on the purchase of hedonic and utilitarian bundles. Journal of Marketing Research, 47(6), 1090-1099.

Ki, C., Lee, K., \& Kim, Y.K. (2017). Pleasure and guilt: how do they interplay in luxury consumption? European Journal of Marketing, 51(4), 722-747.

Kirmani, A., \& Rao, A.R. (2000). No pain, no gain: A critical review of the literature on signaling unobservable product quality. Journal of Marketing, 64(2), 66-79.

Kreul, L.M. (1982). Magic numbers: Psychological aspects of menu pricing. Cornell Hotel and Restaurant Administration Quarterly, 23(2), 70-75.

Lee, J.E., \& Watkins, B. (2016). YouTube vloggers' influence on consumer luxury brand perceptions and intentions. Journal of Business Research, 69(12), 5753-5760.

Macé, S. (2012). The impact and determinants of nine-ending pricing in grocery retailing. Journal of Retailing, 88(1), 115-130.

Mahajan, V., Muller, E., \& Srivastava, R.K. (1990). Determination of adopter categories by using innovation diffusion models. Journal of Marketing Research, 27(1), $37-50$.

Martin, P., \& Chapman, D. (2006). An exploration of factors that contribute to the reluctance of SME owner-managers to employ first destination marketing graduates. Marketing Intelligence \& Planning, 24(2), 158-173.

McCaskey, P.H., \& Brady, D.L. (2007). The current status of course offerings in pricing in the business curriculum. Journal of Product \& Brand Management, 16(5), 358-361.

Michman, R.D., \& Mazze, E.M. (2006). The affluent consumer: Marketing and selling the luxury lifestyle. Greenwood Publishing Group.

Miyazaki, A.D., Grewal, D., \& Goodstein, R.C. (2005). The effect of multiple extrinsic cues on quality perceptions: A matter of consistency. Journal of Consumer Research, $32(1), 146-153$.

Monroe, K.B. (1973). Buyers' subjective perceptions of price. Journal of Marketing Research, 10(1), 70-80. 
Naipaul, S., \& Parsa, H.G. (2001). Menu price endings that communicate value and quality. The Cornell Hotel and Restaurant Administration Quarterly, 42(1), 26-37.

Nightingale, J. (2007). Think smart - Act smart: Avoiding the business mistakes that even intelligent people make. NY: John Wiley \& Sons.

Okada, E.M. (2005). Justification effects on consumer choice of hedonic and utilitarian goods. Journal of Marketing Research, 42(1), 43-53.

Okonkwo, U. (2007). Luxury Fashion Branding: Trends, Tactics, Techniques. Basingstoke: Palgrave Macmillan.

Orme, B., \& Chrzan, K. (2017). Becoming an expert in conjoint analysis: Choice modelling for pros. Sawtooth Software, Inc.: Orem, UT.

Parguel, B., Delécolle, T., \& Valette-Florence, P. (2016). How price display influences consumer luxury perceptions. Journal of Business Research, 69(1), 341-348.

Perreault, W.D., \& McCarthy, E.J. (1999). Basic marketing: A global-managerial approach. Irwin/McGraw-Hill.

Prahalad, C.K., \& Bettis, R.A. (1986). The dominant logic: A new linkage between diversity and performance. Strategic Management Journal, 7(6), 485-501.

Prelec, D., \& Loewenstein, G. (1998). The red and the black: Mental accounting of savings and debt. Marketing science, 17(1), 4-28.

Raghubir, P. (2006). An information processing review of the subjective value of money and prices. Journal of Business Research, 59(10/11), 1053-1062.

Rook, D.W. (1987). The buying impulse. Journal of Consumer Research, 14(2),189199.

Rossi, P.E., Allenby, G.M., \& McCulloch, R.E. (2005). Bayesian statistics and marketing. NewYork: John Wiley \& Sons.

Schindler, R.M. (1991). Symbolic meanings of a price ending. Advances in Consumer Research Volume 18, eds. R. H. Holman and M. R. Solomon, Provo, UT: Association for Consumer Research, 794-801.

Schindler, R.M. (2006). The 99-price ending as a signal of a low-price appeal. Journal of Retailing, 82(1), 71-77.

Schindler, R.M., \& Kibarian, T.M. (1996). Increased consumer sales response though use of 99-ending prices. Journal of Retailing, 72(2), 187-199.

Schindler, R.M., \& Kibarian, T.M. (2001). Image communicated by the use of 99 endings in advertised prices. Journal of Advertising, 30(4), 95-99.

Schindler, R.M., \& Kirby, P.N. (1997). Patterns of rightmost digits used in advertised prices: implications for nine-ending effects. Journal of Consumer Research, 24(2), 192201.

Schindler, R.M., \& Wiman, A.R. (1989). Effects of odd pricing on price recall. Journal of Business Research, 19(3), 165-177. 
Simon, H.A. (1956). Rational choice and the structure of the environment. Psychological Review, 63(2), 129-138.

Slovic, P., Fischhoff, B., \& Lichtenstein, S. (1977). Behavioral decision theory. Annual Review of Psychology, 28(1), 1-39.

Stiving, M. (2000). Price-endings when prices signal quality. Management Science, 46(12), 1617-1629.

Stiving, M., \& Winer, R.S. (1997). An empirical analysis of price endings with scanner data. Journal of Consumer Research, 24(1), 57-67.

Swami, S. (2013). Executive functions and decision making: A managerial review. IIMB Management Review, 25(4), 203-212.

Truong, Y., McColl, R., \& Kitchen, P.J. (2009). New luxury brand positioning and the emergence of masstige brands. Journal of Brand Management, 16(5), 375-382.

Veblen, T. (1899). The theory of the leisure class: An economic study of institutions. New-York: Macmillan.

Vecchiato, R. (2017). Disruptive innovation, managerial cognition, and technology competition outcomes. Technological Forecasting and Social Change, 116, 116-128.

Wiedmann, K.P., Hennigs, N., \& Siebels, A. (2009). Value- based segmentation of luxury consumption behavior. Psychology \& Marketing, 26(7), 625-651.

Wlömert, N., \& Eggers, F. (2016). Predicting new service adoption with conjoint analysis: external validity of BDM-based incentive-aligned and dual-response choice designs. Marketing Letters, 27(1), 195-210.

Yi, S., \& Baumgartner, H. (2011). Coping with guilt and shame in the impulse buying context. Journal of Economic Psychology, 32(3), 458-467.

\section{Web references}

Bain \& Company (2018). Luxury goods worldwide market study, Fall-winter 2018. https://www.bain.com/contentassets/8df501b9f8d6442eba00040246c6b4f9/bain_digest _luxury_goods_worldwide_market_study_fall_winter_2018.pdf (accessed on 2021 July $\left.4^{\text {th }}\right)$.

Business of Fashion (2017). The trouble with Yoox Net-a-Porter. https://www.businessoffashion.com/articles/opinion/the-trouble-with-yoox-net-a-porter (accessed on 2021 July $4^{\text {th }}$ ).

Interbrand (2021). Best global brands 2020. https://www.interbrand.com/best-globalbrands/?filter-brand-sector=luxury (accessed on $2021 \mathrm{July} 4^{\text {th }}$ ).

Sawtooth Software (2017). The CBC system for choice-based conjoint analysis. https://www.sawtoothsoftware.com/download/techpap/cbctech.pdf (accessed on 2021 July $4^{\text {th }}$ ). 


\section{Tables}

Table 1 - Distribution of two-digit price endings for Gucci and LV luxury handbags

(Spring-Summer 2014 to Spring-Summer 2015)

\begin{tabular}{|c|c|c|c|c|c|c|c|c|c|c|c|c|}
\cline { 2 - 12 } \multicolumn{1}{c|}{} & $\begin{array}{c}\text { Mean } \\
\text { price (€) }\end{array}$ & “00" & "10" & “20” & "30" & "40" & "50” & "60" & “70” & "80" “90” \& & Others \\
\hline Gucci (N=582) & 1826 & 224 & & 13 & 16 & & 213 & 5 & 1 & 6 & 97 & 7 \\
\hline LV (N=908) & 2225 & 216 & 35 & 41 & 69 & 56 & 161 & 39 & 27 & 50 & 125 & 89 \\
\hline \multirow{2}{*}{ Total (N=1490) } & 2069 & 440 & 35 & 54 & 85 & 56 & 374 & 44 & 28 & 56 & 222 & 96 \\
\cline { 2 - 11 } & $29,5 \%$ & $2,3 \%$ & $3,6 \%$ & $5,7 \%$ & $3,8 \%$ & $25,1 \%$ & $3,0 \%$ & $1,9 \%$ & $3,8 \%$ & $14,9 \%$ & $6,4 \%$ \\
\hline
\end{tabular}

Table 2 - Results of Study 1

\begin{tabular}{|c|c|c|}
\hline & $\boldsymbol{\beta}$ & $\begin{array}{l}\text { Hypothesis } \\
\text { corroboration }\end{array}$ \\
\hline $\begin{array}{c}-2 \text { Log likelihood } \\
\text { Cox \& Snell } \text { R }^{2}\end{array}$ & $\begin{array}{c}1121.80^{* * * *} \\
0.084\end{array}$ & \\
\hline $\begin{array}{c}\text { Louis Vuitton (vs. } \\
\text { Gucci) }\end{array}$ & $-1.10 * * *$ & \\
\hline $\begin{array}{l}4 \text { in the hundreds place } \\
9 \text { in the hundreds place }\end{array}$ & $\begin{array}{l}0.99 * * * \\
0.65 * *\end{array}$ & $\begin{array}{l}\mathrm{H} 2 \mathrm{a} \text { corroborated } \\
\mathrm{H} 2 \mathrm{~b} \text { corroborated }\end{array}$ \\
\hline $\begin{array}{l}\text { Canvas } \\
\text { Exotic }\end{array}$ & $\begin{array}{l}0.97 * * * \\
-3.05 * * *\end{array}$ & H3a corroborated \\
\hline Conspicuousness & $0.70 * *$ & $\mathrm{H} 3 \mathrm{~b}$ corroborated \\
\hline Residual of price & $-0.55^{*}$ & $\mathrm{H} 3 \mathrm{c}$ corroborated \\
\hline Newness & -0.16 & H3d not corroborated \\
\hline
\end{tabular}

$* \mathrm{p}<.05, * * \mathrm{p}<.01, * * * \mathrm{p}<.001$ (bilateral tests)

Table 3 - Distribution of two-digit price endings for apparel in December 2019

\begin{tabular}{|c|c|c|c|c|c|c|c|c|c|c|c|c|}
\hline & $\begin{array}{c}\text { Mean } \\
\text { price } \\
(€)\end{array}$ & “00" & "10" & “20" & "30" & "40" & “50" & "60" & “70" & "80" & $\begin{array}{c}\text { "90", } \\
\text { "91", } \\
\text { "92" } \\
\& \\
\text { "95" }\end{array}$ & Others \\
\hline Balanciaga $(\mathrm{N}=123)$ & 1053 & & & & & & 52 & & & & 61 & 10 \\
\hline Gucci $(\mathrm{N}=391)$ & 1922 & 173 & & 3 & & & 33 & & & 92 & 72 & 18 \\
\hline Miu Miu (N=167) & 1319 & 33 & & 7 & & & 46 & & 1 & & 80 & 0 \\
\hline Prada $(\mathrm{N}=288)$ & 1391 & 73 & & 19 & 1 & 1 & 110 & 5 & 1 & 9 & 68 & 1 \\
\hline YSL $(\mathrm{N}=109)$ & 1799 & 6 & & 3 & & & 4 & & & & 92 & 4 \\
\hline \multirow{2}{*}{ Total $(\mathrm{N}=1078)$} & \multirow{2}{*}{1575} & 285 & 0 & 32 & 1 & 1 & 245 & 5 & 2 & 101 & 374 & 32 \\
\hline & & $31,3 \%$ & $0,0 \%$ & $3,0 \%$ & $0,1 \%$ & $0,1 \%$ & $17,9 \%$ & $0,5 \%$ & $0,2 \%$ & $9,4 \%$ & $31,6 \%$ & $3,0 \%$ \\
\hline
\end{tabular}


Table 4 - Results of Study 2

\begin{tabular}{|c|c|c|}
\cline { 2 - 3 } \multicolumn{1}{c|}{} & $\boldsymbol{\beta}$ & Hypothesis corroboration \\
\hline -2 Log likelihood & $959.88 * * *$ & \\
Cox \& Snell R & 0.239 & \\
\hline Balenciaga & $-2.57 * * *$ & \\
Gucci & $-3.79 * * *$ & \\
Miu Miu & $-2.30 * * *$ & \\
Prada & $-3.43 * * *$ & H2a not corroborated \\
\hline 4 in the hundreds place & 0.79 & H2b not corroborated \\
9 in the hundreds place & $-.78 * *$ & H3a corroborated \\
\hline Premium materials & $-.62 * *$ & H3c corroborated \\
\hline Residual of price & $-0.62 * * *$ &
\end{tabular}

$* \mathrm{p}<.05, * * \mathrm{p}<.01, * * * \mathrm{p}<.001$ (bilateral tests), YSL as brand baseline

Table 5 - Descriptive statistics for the four clusters: Mean utilities, credible intervals, and median luxury purchase

\begin{tabular}{|c|c|c|c|c|c|}
\hline & Total & Cluster 1 & Cluster 2 & Cluster 3 & Cluster 4 \\
\hline $\begin{array}{c}\mathbf{N} \\
(\%)\end{array}$ & 169 & $43(25.4 \%)$ & $34(20.1 \%)$ & $40(23.7 \%)$ & $52(30.8 \%)$ \\
\hline \multicolumn{6}{|c|}{ Price Utilities: mean and credible intervals $(95 \%)$} \\
\hline 1560 & $\begin{array}{c}0.95 \\
{[0.39 ; 1.52]}\end{array}$ & $\begin{array}{c}3.22 \\
{[2.40 ; 4.04]}\end{array}$ & $\begin{array}{c}2.59 \\
{[1.08 ; 4.10]}\end{array}$ & $\begin{array}{c}-0.36 \\
{[-1.19 ; 0.47]}\end{array}$ & $\begin{array}{c}-0.93 \\
{[-1.90 ;-0.04]}\end{array}$ \\
\hline 1595 & $\begin{array}{c}2.28 \\
{[1.77 ; 2.81]}\end{array}$ & $\begin{array}{c}0.65 \\
{[-0.24 ; 1.54]}\end{array}$ & $\begin{array}{c}5.44 \\
{[4.19 ; 6.69]}\end{array}$ & $\begin{array}{c}3.70 \\
{[2.88 ; 4.53]}\end{array}$ & $\begin{array}{c}0.72 \\
{[0.04 ; 1.41]}\end{array}$ \\
\hline 1600 & $\begin{array}{c}0.06 \\
{[-0.65 ; 0.77]}\end{array}$ & $\begin{array}{c}-1.67 \\
{[-2.56 ;-0.78]}\end{array}$ & $\begin{array}{c}-0.64 \\
{[-2.53 ; 1.25]}\end{array}$ & $\begin{array}{c}-3.04 \\
{[-4.02 ;-2.07]}\end{array}$ & $\begin{array}{c}4.18 \\
{[3.17 ; 5.18]} \\
\end{array}$ \\
\hline 1640 & $\begin{array}{c}-3.30 \\
{[-3.92 ;-} \\
2.68]\end{array}$ & $\begin{array}{c}-2.20 \\
{[-3.36 ;-1.05]}\end{array}$ & $\begin{array}{c}-7.39 \\
{[-8.93 ;-5.85]}\end{array}$ & $\begin{array}{c}-0.30 \\
{[-1.01 ; 0.41]}\end{array}$ & $\begin{array}{c}-3.97 \\
{[-4.79 ;-3.15]}\end{array}$ \\
\hline & & \multicolumn{4}{|c|}{$\begin{array}{l}\text { Median luxury purchase over the previous two years } \\
\qquad(\mathrm{t}=10.3 ; \operatorname{Prob}=0.016)\end{array}$} \\
\hline & & $€ 1750$ & $€ 2800$ & $€ 2125$ & $€ 3755$ \\
\hline
\end{tabular}


Figures

Figure 1 - Examples of the pictures displayed in the CBC

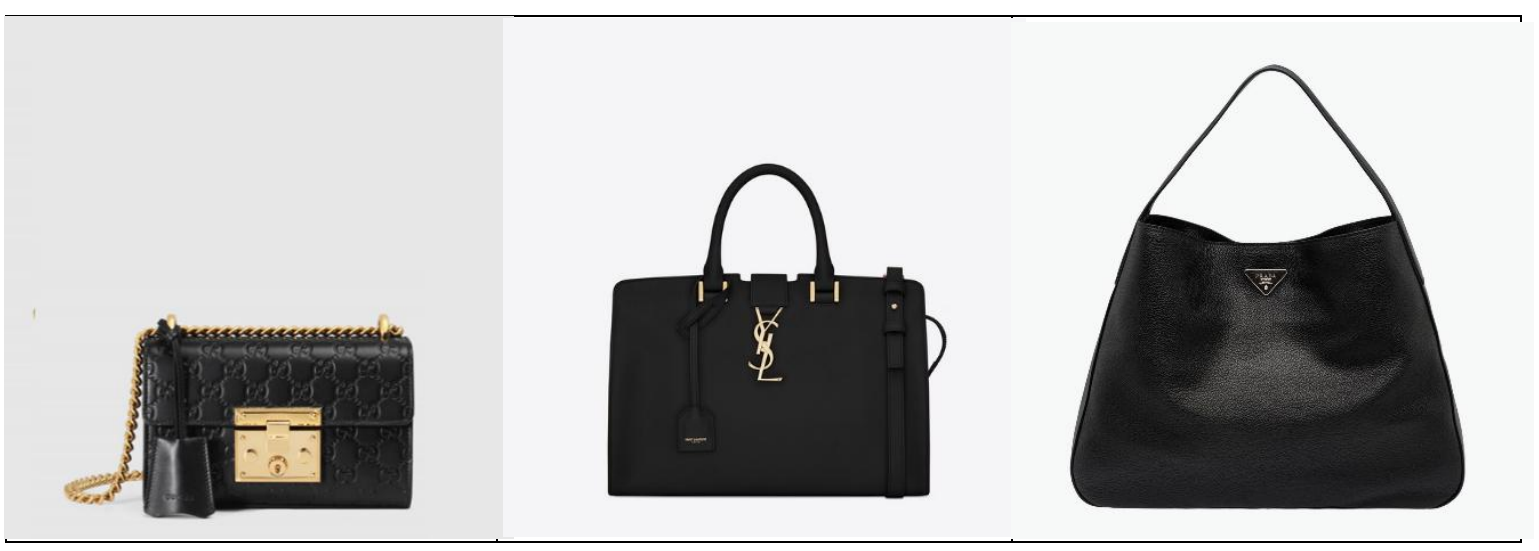

Figure 2 - Means plot for the utilities of the price attribute and error bars (Lower 95\%

$$
\text { CI - Upper 95\% CI) }
$$

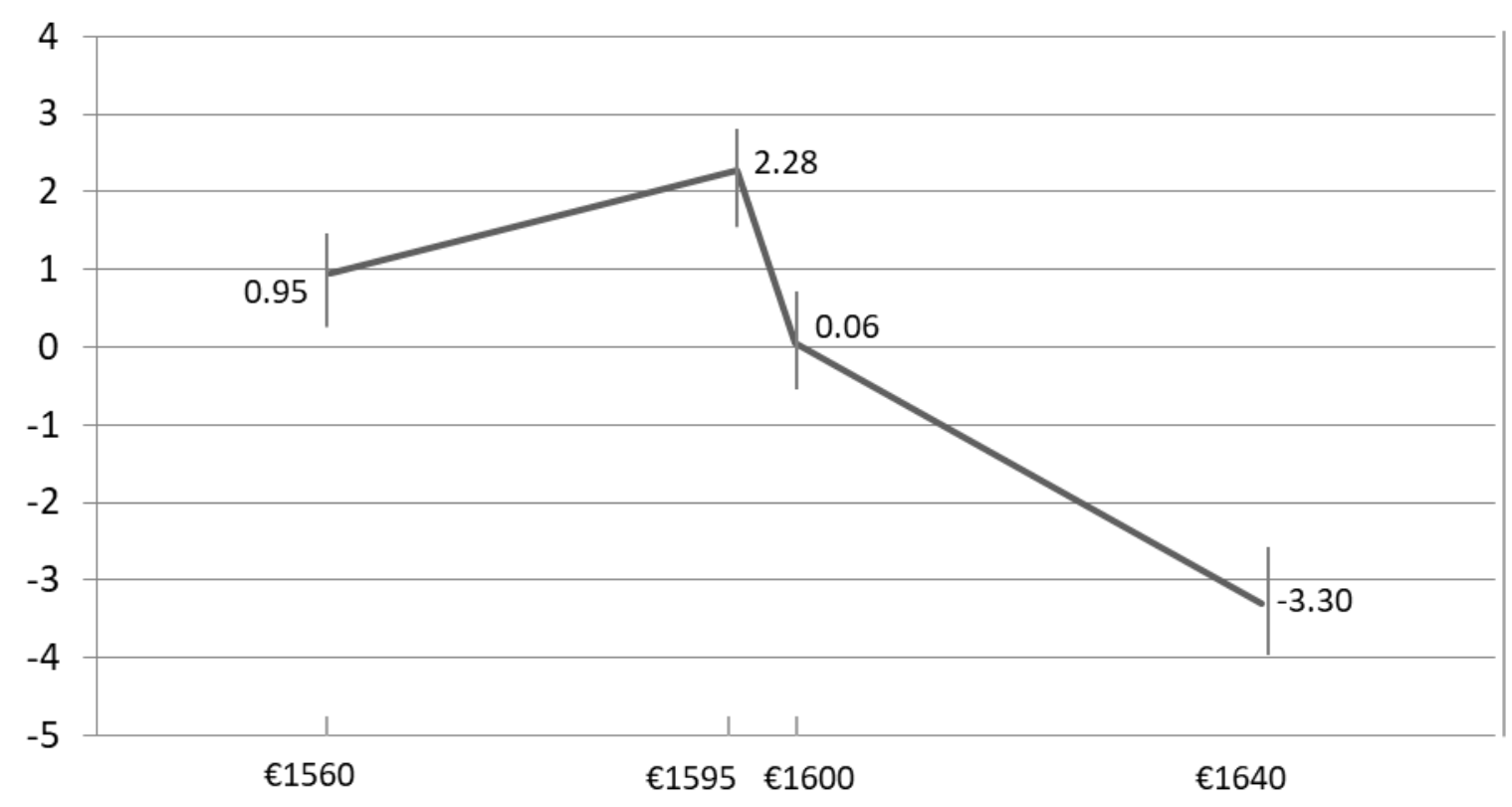

Note: The error values are available in see Table 5 
Figure 3 - Means plots for the utilities of the price attribute per cluster

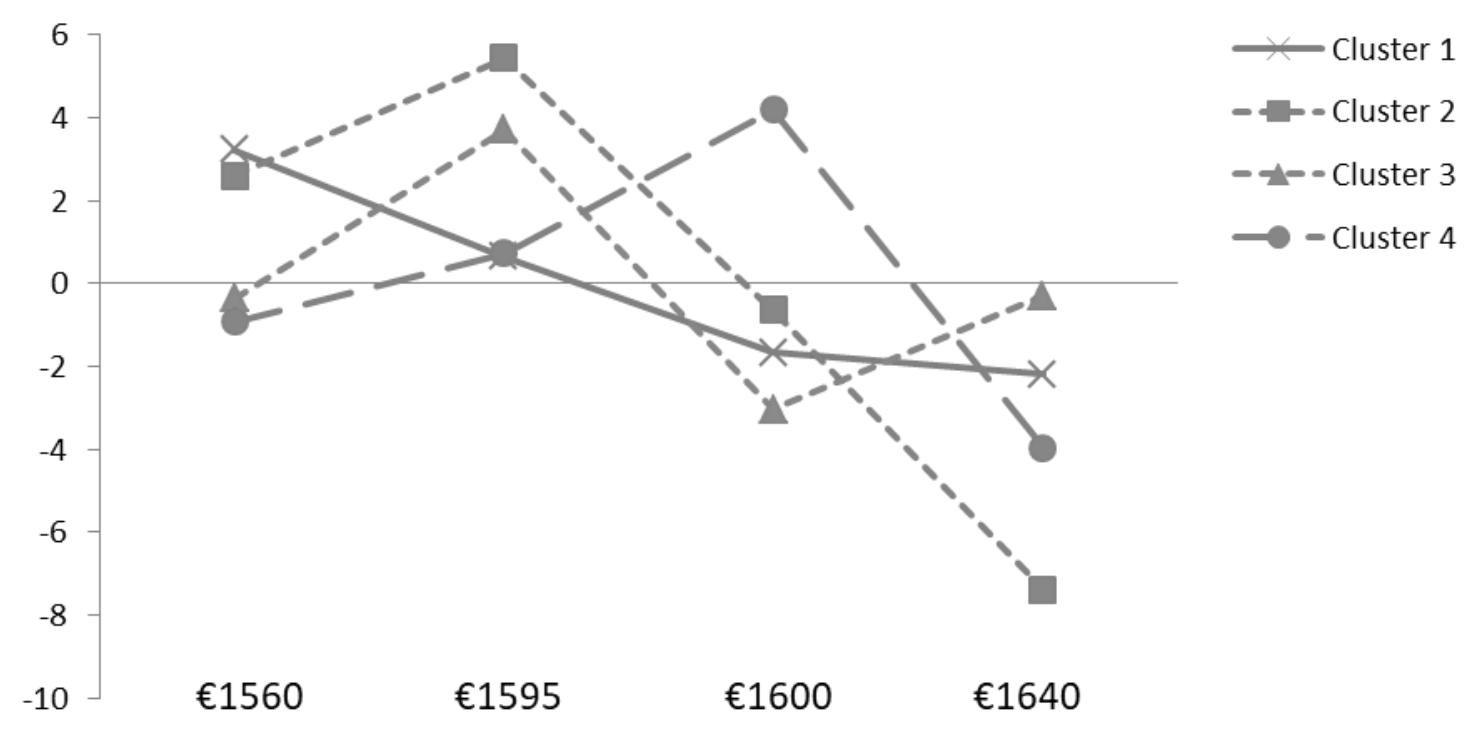

Note: The credible intervals are available in Table 5 